\author{
N. Roslyakova ${ }^{1}$, E. Vechkinzova ${ }^{2, *}$ \\ ${ }^{1,2}$ V.A. Trapeznikov Institute of Control Sciences RAS, Russia, Moscow \\ ${ }^{1}$ roslyakovaNA@gmail.com, ${ }^{2}$ kvin07@list.ru \\ ${ }^{1}$ https://orcid.org/0000-0002-7511-2141, ${ }^{2}$ https://orcid.org/0000-0003-2543-625X, \\ ${ }^{1}$ Scopus Author ID: 57205613193, ${ }^{2}$ Scopus Author ID: 57211264312
}

\title{
Assessment of the impact of labor productivity on the effectiveness of innovative activities in Kazakhstan and the Northwestern Federal District of Russia
}

\begin{abstract}
Object: In many foreign countries, growth in labor productivity leads to a reduction in working hours. But these processes are not always proportional and depend on the correlation of social and economic priorities of states, on the conditions of general globalization and neoliberalization. The unfavorable ratio of the internal price proportions of some states and the low level of development of technics and technology act as obstacles to increasing the rate of economic growth. In such conditions, a reduction in working hours will inevitably lead to a reduction in the country's economic potential and the level of income of citizens. The purpose of this article is to study the nature of labor productivity and analyze the relationship between the proportions of labor productivity and the volume of production of innovative products in Russia and Kazakhstan as the largest EAEU states that determine development trends in the region.

Methods: The collected data on the relationship between labor productivity and the volume of output of innovative products were analyzed using cluster analysis and nonparametric Data Envelopment Analysis (DEA).

Findings: Labor productivity affects the level of innovative development and affects the overall economic development of individual regions and countries as a whole. The analysis of these processes is very important for the formation of state development policy. Therefore, this study examines the relationship between labor productivity and the volume of innovative products, as well as examines similar processes in certain regions of Russia and Kazakhstan.

Conclusions: According to the results obtained, the following hypotheses were accepted: in Kazakhstan and Russia, labor productivity directly affects the innovative production of products. This influence is different in the regions of both countries. In Kazakhstan and Russia, there are regions that are similar in characteristics of the processes of the impact of labor productivity on innovative output, and for them similar measures to improve state policy are recommended.
\end{abstract}

Keywords: labor productivity; innovative production; nonparametric analysis; cluster analysis; data environment analysis; Russia; Northwestern Federal District; Kazakhstan.

\section{Introduction}

In classical political economy, a hypothesis was formulated (which has now become an axiom) that the amount of labor time spent determines the amount of value created, and this, in turn, determines the welfare of the state. Moreover, for a number of states and territories, the amount of working time, and with it "living labor", is the so-called "marginal resource", which determines and restrains (in case of its insufficiency) the growth of total income.

The history of the industrial development of mankind testifies that with the growth of labor productivity, the duration of the working time decreases. At the same time, it is obvious that the rate of reduction of working time is lower than the rate of general economic growth and the rate of growth of labor productivity, precisely because labor time is the main source of an increase in the total mass of income, which is only partially converted into an increase in free time. It can be said that the real proportions of such "partial conversion" depend on the ratio of social and economic priorities of states, along with dependence on the level of labor productivity and the level of development of the country.

Moreover, the process of transformation of labor productivity in free time, which, of course, proceeds at different rates in the countries of the world, is also aggravated by the conditions of general globalization and neoliberalization. These conditions became an important basis for the solution of the "rich" countries of the issue of the heterogeneity of materialized labor, when high-income stages of certain types of economic activity were concentrated on their territory, and low-income ones were transferred to other countries. In essence, the rapid growth in productivity and well-being of the "rich" countries was formed due to the fixation of un-

\footnotetext{
${ }^{*}$ Corresponding author.

E-mail address: kvin07@list.ru
} 
favorable production proportions and over-exploitation of the population of "developing" countries ("poor" countries, countries of the "third" world).

This is the reason for the fundamental impossibility of reducing the general fund of working hours (given the prevailing price ratios) in countries with middle (South Korea, Spain, Italy) and low (Russia, Mexico, Kazakhstan) income levels and relatively long working hours. In such conditions, a reduction in working hours will inevitably lead to a reduction in the economic potential of the country and the level of income of citizens.

In turn, such an unfavorable ratio of the price proportions of these states and the low level of development of technology and technology act as obstacles to the formation of the so-called "middle class", a group of the population that has an average income level and at the same time is majority, which allows it to stabilize the social structure of the state ... Low-income countries with large hours of work are characterized by a smaller (and often insignificantly small) part of the population earning the average income level, while the majority group is represented by people with lower middle income. Therefore, often measures that are aimed at social support of the population are not in the nature of stimulating personal growth and self-improvement of the population, but assistance in solving vital problems, such as buying food, durable goods, paying for utilities.

In this sense, it is important to investigate the nature of labor productivity and assess possible directions for improving public policy. The objects of study were the Russian Federation (RF) and the Republic of Kazakhstan (RK), as the largest EAEU states, which determine development trends in the region.

In Russia and Kazakhstan, there are opposite trends in population dynamics (table 1).

Table 1. Population dynamics in the Russian Federation and the Republic of Kazakhstan in 2013-2017

\begin{tabular}{|c|c|c|c|c|c|}
\hline & 2013 & 2014 & 2015 & 2016 & 2017 \\
\hline & \multicolumn{5}{|c|}{ Natural population growth, thousand people } \\
\hline Russia & 24 & 31 & 32 & -2 & -136 \\
\hline Kazakhstan & 251 & 269 & 266 & 270 & 261 \\
\hline & \multicolumn{5}{|c|}{ Balance of migration of the population, thousand people } \\
\hline Russia & 296 & 271 & 246 & 262 & 212 \\
\hline Kazakhstan & 0 & -12 & -14 & -21 & -22 \\
\hline & \multicolumn{5}{|c|}{ Total } \\
\hline Russia & 320 & 302 & 278 & 260 & 76 \\
\hline Kazakhstan & 251 & 257 & 252 & 249 & 239 \\
\hline
\end{tabular}

It is typical for Russia to compensate for its negative or small natural population growth at the expense of citizens of the EAEU member states, in particular Kazakhstan. This becomes possible because in the EAEU region, Russia has the highest wages and is most provided with a variety of jobs. It is important to note that the unemployment rate in the Republic of Kazakhstan and the Russian Federation is comparable, about $5 \%$ (see table 2).

Table 2. Comparison of the conditions for the functioning of the labor market in the Russian Federation and the Republic of Kazakhstan according to 2018 data

\begin{tabular}{|l|c|c|}
\hline \multicolumn{1}{|c|}{ Index } & Russia & Kazakhstan \\
\hline Unemployment rate & $5.2 \%$ & $4.9 \%$ \\
\hline Informal employment & $20.5 \%$ & $24.5 \%$ \\
\hline Prevailing type of employment contracts & indefinite or long term & for 6-12 months \\
\hline The share of those receiving wages "in envelopes" & up to 40\% & about $0 \%$ \\
\hline The level of wages in terms of dollar equivalent & $\$ 536$ & $\$ 474$ \\
\hline Note - calculated by the authors based on data (Mramornova O.V., Ivanova N.A., Abuova Zh.U., 2018 and Banki24.by, 2019) \\
\hline
\end{tabular}

The level of informal employment is also comparable, that is, these are the people who work on the basis of an oral agreement and are the least protected part of the employed population.

At the same time, one can single out conditions that are definitely more attractive for workers and act as the basis for migration to Russia to earn money. First of all, this is the level of wages, which in Russia is on average 13\% higher than in Kazakhstan. And given the presence of a large percentage of workers who receive "gray" wages, it should be understood that in reality this gap is even greater. Also, an undoubted advantage is the long duration of employment contracts, which increases the employee's sense of stability. 
For further analysis and comparison by the level of labor productivity, we decided to select one federal district of the Russian Federation, which can be considered comparable in size to the Republic of Kazakhstan. We stopped at the Northwestern Federal District (NWFD).

The total GRP of the Northwestern Federal District and the Republic of Kazakhstan in 2018 amounted to 9 and 12.5 billion rubles. (the estimate for the Republic of Kazakhstan was obtained on the basis of the official exchange rate of the tenge to the ruble of the National Bank of Kazakhstan for 2018 www.nationalbank.kz, 2020), which allows us to speak about the relative comparability of economies in scale. A similar situation is observed in terms of the population size, which in 2018 was 14.0 and 18.4 million people. in the Northwestern Federal District and the Republic of Kazakhstan, respectively.

To assess labor productivity, the volume of industrial production is of great importance, which in the Northwestern Federal District is 7028 billion rubles. and 4949 billion rubles. for RK. Already from these data, it becomes clear that the population of the Northwestern Federal District, which is almost 1/3 smaller, is able to obtain a $40 \%$ larger industrial product, which makes the assessment of productivity even more relevant.

These objects of study are also of interest because they have a very diverse internal structure, which makes it possible to distinguish different types of economic relations, for which fundamentally different levels of labor productivity are characteristic. So, in the Northwestern Federal District there is a city of federal subordination (St. Petersburg), and in the Republic of Kazakhstan (RK) the capital city of Nur-Sultan, which accumulates capital functions and has a definitely higher level of income and labor productivity, which, however, have little to do with the manufacturing sector. There are also active highly developed industrial centers in the Karaganda and East Kazakhstan regions (RK) and the Leningrad and Novgorod regions (NWFD). In addition to them, there are large centers of the mining industry Atyrau, Kyzylordy, North Kazakhstan regions in the Republic of Kazakhstan and Murmansk, Arkhangelsk regions and the Komi Republic in the Northwestern Federal District.

Taking these features into account, it was decided to cluster the regions of the Northwestern Federal District and the Republic of Kazakhstan in order to identify more homogeneous groups. Further, in homogeneous groups, conduct a nonparametric analysis of the relationship between the output of innovative products and the level of labor productivity.

The main hypothesis of this study: in Kazakhstan and Russia, labor productivity directly affects the innovative production of products. This influence is different in the regions of both countries. In Kazakhstan and Russia, there are regions that are similar in characteristics of the processes of the impact of labor productivity on innovative output and for them similar measures to improve state policy can be recommended.

\section{Literature Review}

Studies of the relationship between labor productivity and the level of economic development of the state and its households have been carried out over the past fifty years in various sectors of the economy and countries.

Bernanke B.S. and Parkinson M.L. (Bernanke B.S., Parkinson M.L., 1991) presented the results of a study of short-run increasing returns to labor (SRIRL) in a sample of 10 US manufacturing industries between the two world wars. They took out the impact of a procyclical technology shock on SRIRL.

Sparks C. and Greiner M. (Sparks C., Greiner M., 1997) investigate comparative trends in manufacturing productivity and unit labor costs for the period 1979-1995 in the United States, as well as conduct a comparative analysis of labor productivity in 1994-1995. years of the United States with other countries. They conclude about the impact of technological development on labor productivity and competitiveness of manufactured goods in the United States.

Lovegrove N.C., Fidler S., Harris V.J. (Lovegrove N.C., Fidler S., Harris V.J., 1998) consider the causes of low labor productivity in the UK. The article compares with the overall performance of the United States and compares the performance of UK companies with those of the world's leading companies in the automotive, food processing, food retail, hotels, software and telecommunications industries. Among other findings, the authors focus on technical development and the impact of product market regulation on productivity.

Van Ark B. (Van Ark B., 1999) presents a transnational study that revealed differences in labor productivity and living standards, which are quantitatively and qualitatively large across countries and regions.

Garcia P., Knights P.F., Tilton J.E. in their article note that over the past two decades, labor productivity in the copper industry has sharply increased both in Chile and in the United States. Research attributed the production growth mainly to innovation and technological change, rather than the development of higher 
quality copper deposits due to the development of new mines and the shift in production from mines with low productivity to mines with high productivity. Although better copper deposits are more important in Chile than in the United States, innovation and technological change have contributed significantly to productivity growth in Chile as well. Thus, the article emphasizes a direct connection between labor productivity and innovative development of production (Garcia P., Knights P.F., Tilton J.E., 2001).

At the International Labor Conference, the Chairman of the Government of the Russian Federation D.A. Medvedev came up with an initiative to reduce the working week for Russians from the current 5 to 4 days. Referring to the successful modern experience of foreign countries, the Prime Minister noted that this is a serious basis for the growth of labor productivity, on the one hand, and freeing up time for the selfdevelopment of citizens, on the other hand (Medvedev, 2019).

Golikova, in subsequent comments, noted that the level of wages may either remain or be lower due to a reduction in the volume of working hours (Golikova, 2019). Taking into account international agreements, according to which any innovations in the world of work should not worsen the position of the worker, the question arises about the conditions in which such a rapid increase in productivity can take place.

Goridko N.P. emphasizes that for a number of states and territories, the amount of working time, and with it "living labor", is the so-called "marginal resource", which determines and restrains (in case of its insufficiency) the growth of total income. In particular, this state of affairs is typical for the Russian Arctic, the work (Goridko NP, 2016) provides estimates of the potential GRP for the Arkhangelsk and Murmansk regions, the Republics of Karelia and Yakutia (Sakha), on the basis of which it is proved that the economy has significant growth potential due to involving additional labor.

Minakir P.A. notes that the history of the industrial development of mankind shows that with an increase in labor productivity, the duration of working hours decreases. At the same time, it is obvious that the rate of reduction of working time is lower than the rate of general economic growth and the rate of growth of labor productivity, precisely because labor time is the main source of increase in the total mass of income, which is only partially converted into an increase in free time (Minakir P.A., 2019).

He also identifies two groups of conditionally "rich" countries, which have different attitudes towards working hours. The first group (USA, Japan, Canada) sees a priority in increasing the welfare and income level for citizens and building up the economic potential for the state. On the other hand, Germany, France, Switzerland considers personal freedom and development as an unconditional priority. As a result, the first increase in productivity is directed to additional labor activity, and the second to reduce working hours.

Roslyakova N.A. and Novikov A.B. (Roslyakova N.A., Novikov A.B., 2019) emphasize that the process of transformation of labor productivity in free time, which, of course, takes place at different rates in the countries of the world, is also aggravated by the conditions of general globalization and neoliberalization.

Kazmina I. et al. in the article investigate the role of the 4th industrial revolution in the growth of labor productivity. Considering that sustainable development of the economy is associated not only with the progress of Industry 4.0, but also with the improvement of the labor market in advanced economies, which creates new jobs, professions and personnel (Kazmina I., Lukyanov P., Zhminko N., Savchenko I., Yusupova G., Zatsarinnaya E., 2020).

Thus, these conditions became an important basis for the solution of the "rich" countries of the issue of the heterogeneity of materialized labor, when high-income stages of certain types of economic activity were concentrated on their territory, and low-income ones were transferred to other countries. In essence, the rapid growth in productivity and prosperity of the "rich" countries was formed by fixing unfavorable production proportions and over-exploitation of the population of the "developing" countries ("poor" countries, countries of the "third" world).

\section{Methods}

In the study, we examined 27 regions, 11 regions of the Northwestern Federal District and 16 regions of Kazakhstan.

At the first stage of the study, the clustering method was used. Clustering or cluster analysis groups many objects into a subset in such a way that the objects of one cluster are as similar to each other as possible, and objects from different clusters have the maximum number of criteria that are different from each other.

As a result of the cluster analysis, groups of regions with similar development trends were identified; it was carried out for individual years in the period from 2015 to 2017. Labor productivity and the release of innovative products were chosen as the classification features, as an expression of the most high-tech production activity. All indicators have been normalized. 
We chose the k-means clustering method. The k-means method is a cluster analysis method, the purpose of which is to divide all available observations of observations into k clusters, with each observation belonging to the cluster to the center of which it is closest. As a measure of proximity, we used the Euclidean distance.

The analysis of the relationship between the output of innovative products and the level of labor productivity was carried out using the method of nonparametric analysis - data environment analysis, which is based on M. Farrell's neoclassical approach to assessing the technical efficiency of resources in a stochastic boundary production function (Farrel J. Michael, 1957).

When comparing a set of objects (decision making units, DMU) by the number of resources used and the results obtained, those objects are recognized as technically efficient that provide the maximum output per unit of resources spent.

The essence of the method is that for a certain set of objects (DMU), represented by enterprises, firms, regions, etc., reference objects are determined, characterized by the best indicators of return on the use of resources (the ratio of the product / result to the resource / costs).

If, with an increase in the amount of a resource, its return in the reference objects does not decrease (the products increase proportionally), then such reference objects are at the border of production capabilities with a constant effect of scale - CRS (Constant Returns to Scale), which represents the bisector on the coordinate system of consumed resources and manufactured products. If, with an increase in the amount of a resource, its return changes (products increase disproportionately), then the boundary of production possibilities represent the shape of a curve passing through objects with the least amount of consumed resources - the boundary of production possibilities with variable returns to scale - VRS (Variable Returns to Scale).

The technical efficiency of facilities lying on the production capability boundary is equal to one.

The main attractive property of the DEA method is related to the fact that efficiency is calculated for each object using one aggregate indicator, without imposing restrictions on the functional form of the relationship between costs and performance, and identifies real objects with "best practice" as reference, rather than calculating averaged trends / indicators.

\section{Results}

According to the Euclidean distance method, the most reliable estimates were obtained for 4 clusters, therefore, further 3 clusterings were carried out for each year using the k-means method, focused on obtaining four clusters. Generalizations about the received groups are presented in table 3.

Table 3. Clustering results, typical regions and an estimate of the cluster average productivity

\begin{tabular}{|c|c|c|c|c|c|}
\hline & & Cluster 1 & Cluster 2 & Cluster 3 & Cluster 4 \\
\hline \multirow{3}{*}{$\stackrel{n}{\frac{\pi}{2}}$} & Typical region & $\begin{array}{l}\text { Akmola region } \\
\text { Novgorod region }\end{array}$ & $\begin{array}{c}\text { West Kazakhstan region } \\
\text { Leningrad region }\end{array}$ & Atyrau region & $\begin{array}{l}\text { Vologda region } \\
\text { Nur-Sultan }\end{array}$ \\
\hline & $\begin{array}{l}\text { Number of } \\
\text { regions }\end{array}$ & 16 & 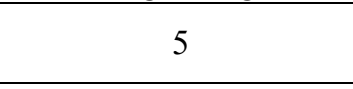 & 4 & 2 \\
\hline & $\begin{array}{l}\text { Average labor } \\
\text { productivity }\end{array}$ & 0.2 & 0.4 & 0.9 & 0.5 \\
\hline \multirow{3}{*}{ 울 } & Typical region & Pavlodar region & Vologda region & Atyrau region & $\begin{array}{l}\text { St. Petersburg } \\
\text { Nur-Sultan }\end{array}$ \\
\hline & $\begin{array}{l}\text { Number of } \\
\text { regions }\end{array}$ & 17 & 5 & 3 & 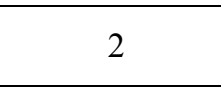 \\
\hline & $\begin{array}{l}\text { Average labor } \\
\text { productivity }\end{array}$ & 0.2 & 0.4 & 0.9 & 0.8 \\
\hline \multirow{3}{*}{ 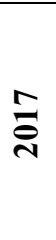 } & Typical region & $\begin{array}{c}\text { Novgorod region } \\
\text { North Kazakhstan region }\end{array}$ & $\begin{array}{l}\text { Arkhangelsk region } \\
\text { Pavlodar region }\end{array}$ & Almaty & $\begin{array}{l}\text { St. Petersburg } \\
\text { Nur-Sultan }\end{array}$ \\
\hline & $\begin{array}{l}\text { Number of } \\
\text { regions }\end{array}$ & 16 & 2 & 7 & 2 \\
\hline & $\begin{array}{l}\text { Average labor } \\
\text { productivity }\end{array}$ & 0.2 & 0.3 & 0.7 & 0.8 \\
\hline
\end{tabular}

From Table 3, it can be seen that the most numerous is the group of regions with the lowest labor productivity, which partly confirms the problems described above. Then there are the few groups with higher labor productivity, among which the capital cities occupy a special place (cluster 4 in 2016-2017). Figure 1 shows the average values obtained for clusters in different years. 


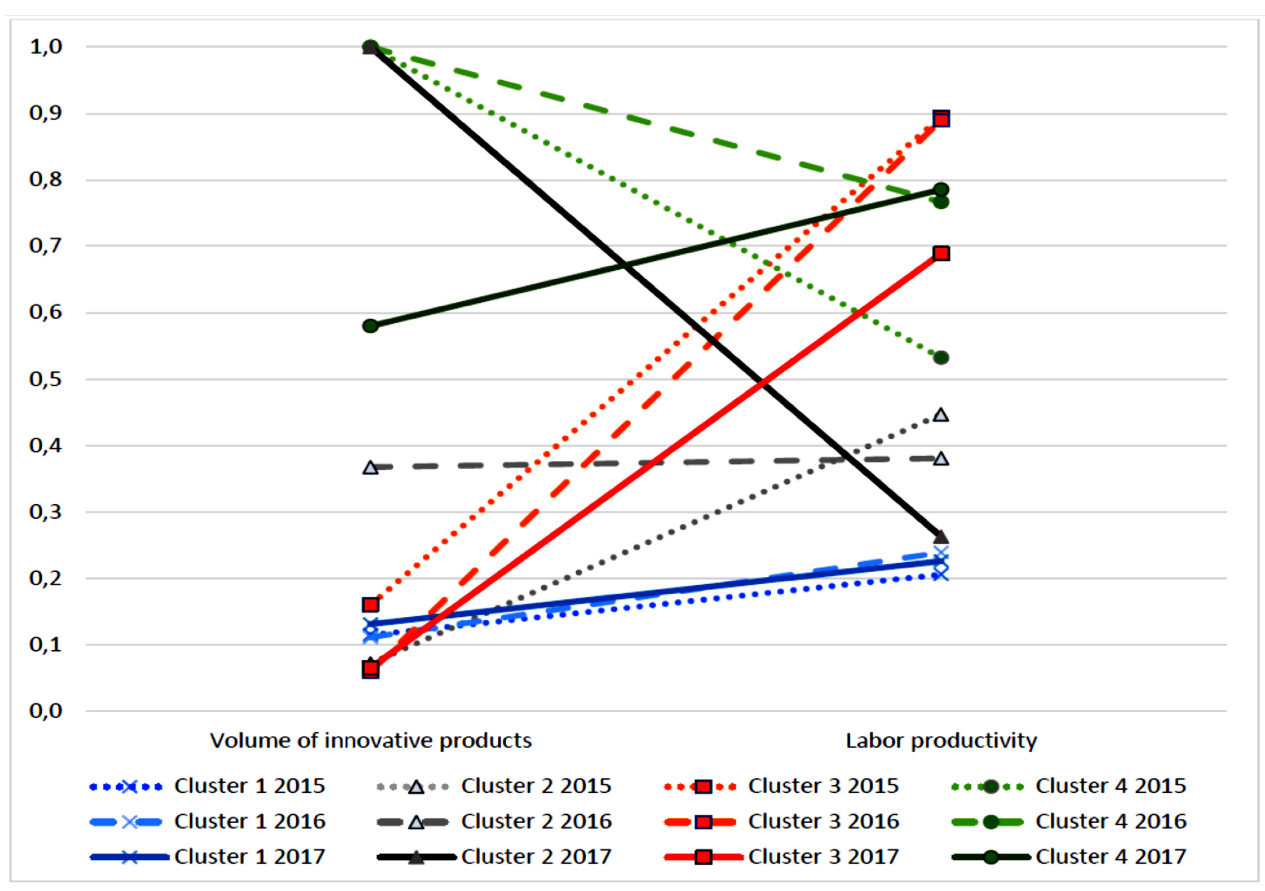

Figure 1. Graph of average values of parameters for clusters in different years (2015-2017)

Note - compiled by authors.

The graph shows cluster 1 , the regions of which, having relatively low labor productivity, have extremely low rates of innovative production. Also noteworthy is cluster 3, where, with high labor productivity, there is an extremely low output of innovative products.

Cluster 1 can be classified as depressed regions with low potential for technological renewal and economic growth. We can say that these are the regions in which at the interregional level there are the lowest (unfavorable for regional producers) prices, which lead to the oppression of production activities and the outflow of labor resources to more favorable regions.

Cluster 3 - these are regions that are typical producers of traditional products (first of all, this concerns the extraction and production of primary resources), it should be noted that this group is expanding, which indicates the conditions in which it is beneficial to switch to the production of primary products, because only it is competitive (the consequences of globalization discussed above). Often, such industries are wellequipped and have a fairly high technological level, but all this concerns the means of labor. The subject of labor and, accordingly, the resulting product cannot become traditional and innovative here. The most important basis for technological development and expansion of production in such regions, in our opinion, is the market capacity. So, researchers (Petrenko E.S., Vechkinzova E.A., Urazbekov A.K., 2019) note that there is often no need to purchase the most modern and high-performance equipment, since it will be idle most of the time or work conditionally at $1 / 10$ of its maximum productivity. That is, the potential for development here lies in the expansion of production of higher value added, which could become consumers and processors of the increased flow of traditional goods (resources).

Regarding cluster 4, we made remarks above that the metropolitan position allows for a large volume of production of innovative products, rather due to the favorable price ratio, which stimulates the production of more expensive products, and the presence of a large number of diverse and qualified personnel. In our opinion, the level of labor productivity for the production of innovative products is not a cornerstone.

Of interest is cluster 2, which was the most unstable in composition for the 3 years under consideration and judging by the significant change in the volume of innovative products output against the background of a relatively stable level of labor productivity, we can say that these are the regions that have undergone the greatest transformations associated with the establishment and launch of innovative industries. however, it should be noted that this group of regions decreases from 5 to 2 regions, that is, the processes taking place in them are not typical.

The next stage of the study was to analyze the relationship between the release of innovative products and the level of labor productivity. To obtain such estimates, we used DEA (Roslyakova N.A., 2018). The use of a single parameter as an input (performance) to form a single output (innovative products) allows 
you to eliminate the action of other factors and highlight the influence of only the performance parameter, it also opens up opportunities for visualizing the results. Since there are restrictions on constructing estimates for several regions (in particular, in 2017, clusters 2 and 4 had only 2 regions each), estimates will be built for clusters 1 and 3. We also oriented the model towards the output in order to find the answer to the question on question: what volume of innovative products can be obtained at the current level of labor productivity.

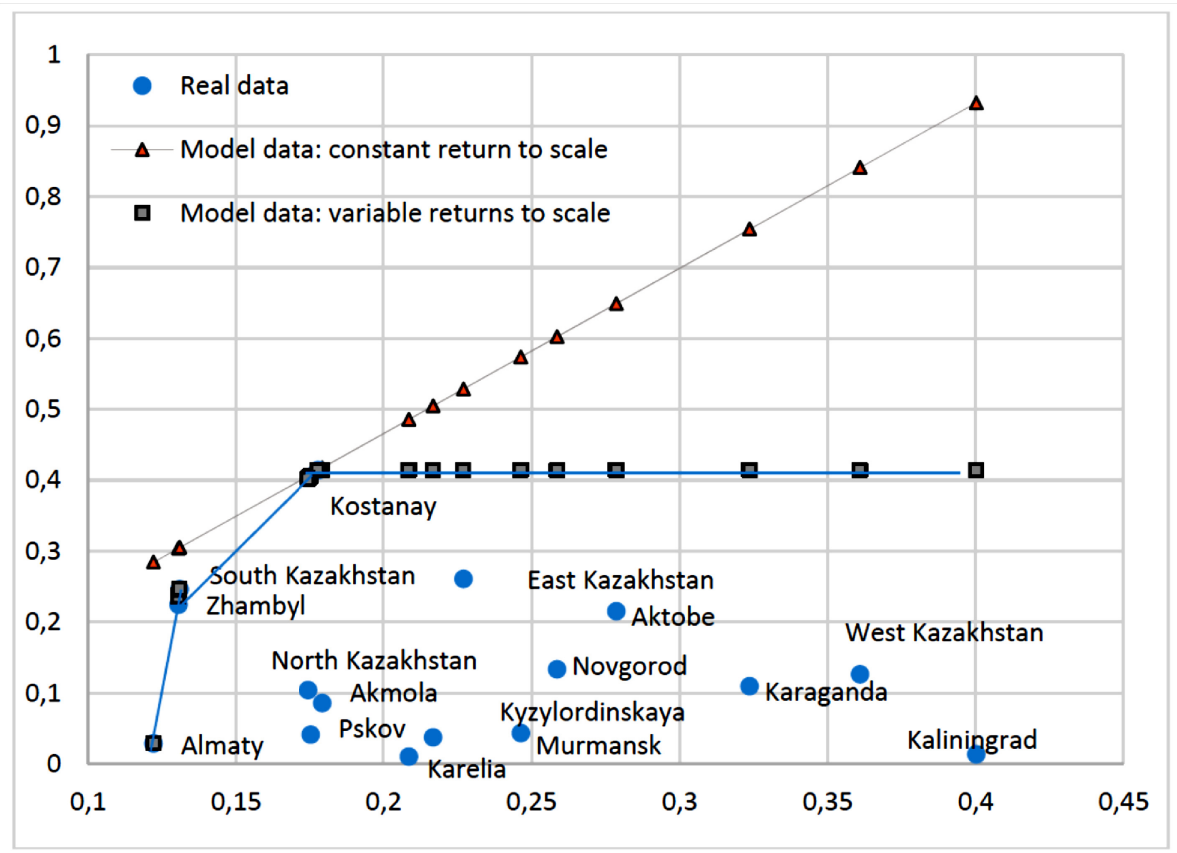

Figure 2. Estimates of the optimal level of innovative production at a given level of productivity for models with constant (CRS) and variable (VRS) scales for the regions of cluster 1 according to 2017 data.

Note - compiled by authors.

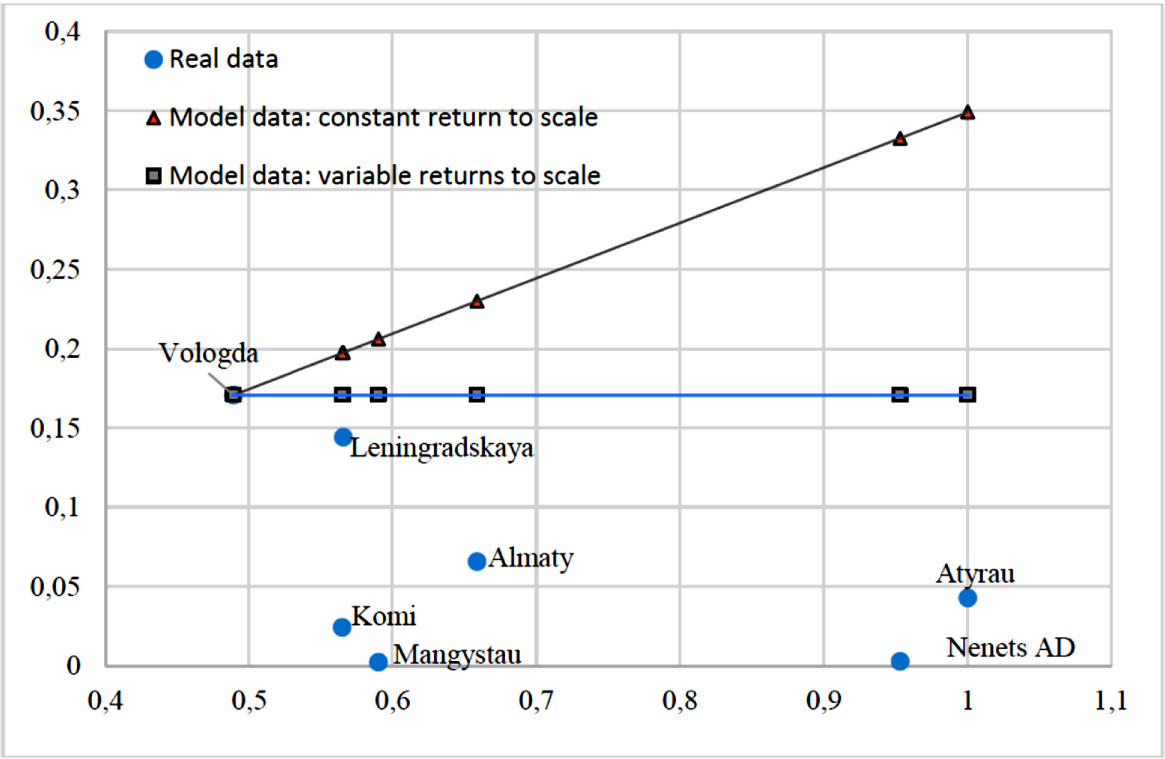

Figure 3. Estimates of the optimal level of innovative production at a given level of productivity for models with constant (CRS) and variable (VRS) scales for the regions of cluster 3 according to 2017 data.

Note - compiled by authors.

Figures 2 and 3 show that the option with increasing returns seems more realistic, since there is a certain limit on the output of innovative products that is available to the regions. It can be understood that this level of production of innovative products for the regions of cluster 1 corresponds to the indicators of the 
Kostanay region of the Republic of Kazakhstan in 2017 (given in rubles). For cluster 3, it corresponds to the output level of the Vologda region.

\section{Conclusions}

In our opinion, in order to resolve these issues, it is necessary to develop new forms of economic activity that will eliminate the contradictions inherent in the neoliberal and neoindustrial concepts, when the goals of socializing the economy are proclaimed, strengthening the social orientation of economic growth and development, but at the same time there is a primacy of market competitiveness, which should ensured primarily due to the flexibility of the labor market, which leads to the emergence of more and more sophisticated forms of exploitation of labor, knowledge, qualifications, quality of life.

For the regions of cluster 1, such decisions may be associated with supporting the development of SMEs (small and medium-sized businesses) among the self-employed and unemployed population based on the development of microcrediting. Moreover, the Republic of Kazakhstan has a positive experience in this area, so in 2017, 7,227 such loans were issued in the amount of about 32 billion tenge (an average size of 4.42 million tenge). In 2018, about 14 thousand people attracted loans for business in the amount of 62 billion tenge. At the same time, on the Russian microcredit market with a volume of 121 billion rubles (about 650 billion tenge), the share of loans to support SMEs is negligible. We can say that in Russia there is no instrument as such.

Also, in Kazakhstan, there is a bias towards lending and supporting SMEs in rural areas (up to $83 \%$ of all planned microcredits in 2019-2021 are targeted at rural areas). At the same time, the documents of the Russian Federation do not indicate the problem of developing SMEs outside the regional centers. There are monotowns as a focus.

On the other hand, in Kazakhstan, there is a lack of competence of potential entrepreneurs, especially from rural areas, which hinders their successful work. Here, the experience of Russia in the formation of regional teams with professional economists-curators for the development of the level of professional training of future entrepreneurs and the development of a business plan can be useful here.

For cluster 3 , where there is a fairly large business that is concentrated on the production of primary resources, it is important to establish new industries that will act as consumers of resources and will allow the professional development of the population to be realized, ensuring an increase in productivity and income. It is also worth noting that the development of public-private partnership mechanisms in this area allows to ensure the flow of private funds and form the basis for attracting services and products from SMEs to such projects.

\section{References}

Bernanke B.S., Parkinson M.L. (1991). Procyclical labor productivity and competing theories of the business cycle: some evidence from... Journal of political economy, V. 99, No 3, 439-459.

Farrel J. Michael (1957), The measurement of Productive efficiency. Journal of the Royal Statistical Society, Series A, General 125, Part 2, 252-267.

Garcia P., Knights P.F., Tilton J.E. (2001). Labor productivity and comparative advantage in mining: the copper industry in Chile. Resources policy, V. 27, No 2, 97-105.

Golikova: vopros o zarplate pri perekhode na 4-dnevnuyu rabochuyu nedelyu ostayetsya otkrytym [Golikova: the question of wages when switching to a 4-day working week remains open]. Sait Informatsionnogo agentstva «TASS» [Site of News Agency "TASS"]. tass.ru. Retrieved from https://tass.ru/ekonomika/6539080 [in Russian].

Gorid'ko, N.P. (2016). Osobennosti ekonomicheskogo razvitiya regionov Severa i Arktiki: rynok truda i regressionnoye modelirovaniye potentsial'nogo valovogo regional'nogo produkta [Features of the economic development of the regions of the North and the Arctic: the labor market and regression modeling of the potential gross regional product]. Regional'naya ekonomika: teoriya i praktika - Regional economy: theory and practice, 5, 121-136 [in Russian].

Sravnivayem. Zarabotnaya plata v stranakh SNG v 2018-m godu [Let's compare. Salaries in the CIS countries in 2018]. Sait informatsionno-spravochnyy portal «Banki 24.by» [Site of Information and reference portal "Banki24.by"]. https://banki24.by. Retrieved from https://banki24.by/news/3113-sravnivaem-zarabotnaya-plata-v [in Russian].

Lovegrove N.C., Fidler S., Harris V.J. (1998). Why is labor productivity in the United Kingdom so low? McKinsey quarterly, 4, 44-57.

Kazmina I., Lukyanov P., Zhminko N., Savchenko I., Yusupova G., Zatsarinnaya E. (2020). Fourth industrial revolution-engineering innovations for labor productivity increasing. Talent development and excellence, $\mathrm{V} .12$, No 1.3,477-487.

Medvedev: budushcheye - za chetyrekhdnevnoy rabochey nedeley [Medvedev: the future belongs to a four-day work week]. Sait Informatsionnoye agentstvo «Vesti.ru» [Site of News Agency "Vesti.ru"]. www.vesti.ru. Retrieved from https://www.vesti.ru/doc. html?id=3156958 [in Russian]. 
Minakir, P.A. (2019). Rabotat' nel'zya otdykhat' [You cannot rest to work]. Prostranstvennaya ekonomika - Spatial economics, Vol. 15, 3, 7-19 [in Russian].

Miropol'skiy, D.Yu., \& Yakshibayeva, G.V. (2018). Sostoyaniye i perspektivy razvitiya trudovoy migratsii Rossii s gosudarstvami-chlenami YEAES kak faktor ustoychivogo sotsial'no-ekonomicheskogo razvitiya [The state and prospects for the development of labor migration in Russia with the EAEU member states as a factor of sustainable socio-economic development]. Izvestiya Sankt-Peterburgskogo gosudarstvennogo ekonomicheskogo universiteta Bulletin of St. Petersburg State University of Economics, 4 (112), 29-37 [in Russian].

Mramornova, O.V., Ivanova, N.A. \& Abuova, Zh.U. (2018). Vozniknoveniye i razvitiye prekariata v Rossiyskoy Federatsii i Respublike Kazakhstan: sravnitel'nyy analiz [The emergence and development of the precariat in the Russian Federation and the Republic of Kazakhstan: a comparative analysis]. Izvestiya Saratovskogo universiteta. Novaya seriya. Seriya Ekonomika. Upravleniye. Pravo - Bulletin of the Saratov University. New series. Series Economics. Control. Law, 8 (3), 259-266 [in Russian].

Mukhopadhyay T., Lerch F.J., Mangal V. (1997). Assessing the impact of information technology on labor productivity a field study. Decision support systems, V.19, No 2, 109-122.

Ofitsial'nyye kursy inostrannykh valyut v srednem za period [Official exchange rates of foreign currencies on average for the period]. Sayt Natsional'nogo banka Kazakhstana [site of the National Bank of Kazakhstan]. www.nationalbank.kz. Retrieved from https://www.nationalbank.kz/?docid=763\&switch=rus [in Russian].

Petrenko, Ye.S., Vechkinzova, Ye.A. \& Urazbekov, A.K. (2019). Analiz sostoyaniya i perspektivy razvitiya gornometallurgicheskoy otrasli Kazakhstana [Analysis of the state and development prospects of the mining and metallurgical industry in Kazakhstan]. Ekonomicheskiye otnosheniya - Economic Relations, Vol. 9, 4, $2661-2676$ [in Russian].

Roslyakova, N.A. (2018). Ispol'zovaniye metodiki DEA dlya otsenki perspektiv innovatsionnogo razvitiya SeveroZapada [Using the DEA methodology to assess the prospects for innovative development in the North-West]. Proceedings from Multifactorial challenges and risks in the context of the implementation of the strategy of scientific, technological and economic development of the macroregion "North-West" '18: Vserossiyskaia nauchnoprakticheskaia konerentsiia (23-24 oktyabrya 2018) - Russian scientific-practical conference (p. 67-73). Saint Petersburg: Publishing GUAP [in Russian].

Roslyakova, N.A., \& Novikov, A.B. (2019). Problemy formirovaniya i razvitiya srednego klassa v menyayushchemsya mire [Problems of the formation and development of the middle class in a changing world]. Izvestiya SanktPeterburgskogo gosudarstvennogo ekonomicheskogo universiteta - Bulletin of the St. Petersburg State Economic University, 4 (118), 115-118 [in Russian].

Sparks C., Greiner M. (1997). U.S. and foreign productivity and unit labor costs. Monthly labor review, V. 120, No 2, 26-35.

Van Ark B. (1999). International comparisons of labor productivity and per capita income. Monthly labor review, V. 122, No.7, 33-41.

\section{Н. Рослякова, Е. Вечкинзова}

\section{Қазақстанда және Ресейдің Солтүстік-Батыс федералдық округінде еңбек өнімділігінің инновациялық қызметтің тиімділігіне әсерін бағалау}

\section{Aндаmna:}

Maқ̧cambl: Көптеген шет елдерде еңбек өнімділігінің өсуі жұмыс уақытының қысқаруына алып келеді. Бірақ бұл процестер әрдайым пропорционалды емес және мемлекеттердің әлеуметтік-экономикалық басымдықтарының арақатынасына, жалпы жаһандану мен неолиберализация жағдайларына байланысты. Кейбір мемлекеттердің ішкі баға пропорцияларының қолайсыз арақатынасы және технологиялар мен технологиялардың дамуының төмен деңгейі экономикалық өсу қарқынын арттыруға кедергі болып табылады. Мұндай жағдайларда жұмыс уақытының қысқаруы сөзсіз, яғни елдің экономикалық әлеуеті мен азаматтардың табыс деңгейінің төмендеуіне әкеледі. Осы мақаланың мақсаты еңбек өнімділігінің сипатын зерттеу және өңірдегі даму үрдістерін айқындайтын ЕАЭО-ның ең ірі мемлекеттері ретінде Ресей мен Қазақстанның Еңбек өнімділігі пропорциялары мен инновациялық өнім шығару көлемінің өзара байланысын талдау болып табылады.

Әдісі: Еңбек өнімділігі мен инновациялық өнім шығару көлемі арасындағы өзара байланыс туралы жиналған деректерді кластерлік талдау және параметрлік емес талдау — Data Envelopment Analysis (DEA) әдістерін пайдалана отырып талданды.

Қорытынды: Еңбек өнімділігі инновациялық даму деңгейімен тығыз байланысты және жекелеген өңірлер мен тұтастай елдердің жалпы экономикалық дамуына әсер етеді. Бұл процестерді талдау мемлекеттік даму саясатын қалыптастыру үшін өте маңызды. Сондықтан осы зерттеуде еңбек өнімділігі мен инновациялық өнім шығару көлемі арасындағы өзара байланыс талданған, сондай-ақ Ресей мен Қазақстанның жекелеген өңірлеріндегі ұқсас процестер көрсетілген.

Тұжырымдама: Алынған нәтижелерге сәйкес мынадай гипотезалар қабылданды: Қазақстан мен Ресейде еңбек өнімділігі өнімнің инновациялық шығарылуына тікелей әсер етеді. Бұл әсер екі елдің аймақтарында әр 
түрлі. Қазақстан мен Ресейде еңбек өнімділігінің инновациялық шығарылымға әсер ету процестерінің сипаттамалары бойынша ұқсас өңірлер бар және олар үшін мемлекеттік саясатты жетілдірудің ұқсас шаралары ұсынылған.

Kiлm сөздер: еңбек өнімділігі, инновациялық өндіріс, кластерлік талдау, жұмыс істеу ортасын параметрлік емес талдау (DEA), Ресей, Солтүстік-Батыс федералдық округі, Қазақстан.

\section{Н. Рослякова, Е. Вечкинзова}

\section{Оценка влияния производительности труда на эффективность инновационной деятельности в Казахстане и Северо-Западном федеральном округе России}

\section{Аннотация}

Цель: Во многих зарубежных странах рост производительности труда ведет к сокращению рабочего времени. Но не всегда эти процессы пропорциональны и зависят от соотношения социальных и экономических приоритетов государств, условий всеобщей глобализации и неолиберализации. Невыгодное соотношение внутренних ценовых пропорций некоторых государств и низкий уровень развития техники и технологии выступают препятствиями для увеличения темпов экономического роста. В подобных условиях сокращение рабочего времени неизбежно будет вести к сокращению экономического потенциала страны и уровня дохода граждан. Целью данной статьи является исследование характера производительности труда и анализ взаимосвязи пропорций производительности труда и объема выпуска инновационной продукции России и Казахстана как самых крупных государств ЕАЭС, которые определяют тенденции развития в регионе.

Memoдbl: Собранные данные о взаимосвязи между производительностью труда и объемом выпуска инновационной продукции были проанализированы с использованием методов кластерного анализа и непараметрического анализа - Data Envelopment Analysis (DEA).

Результаты: Производительность труда тесно связана с уровнем инновационного развития и оказывает влияние на общее экономическое развитие отдельных регионов и стран в целом. Анализ этих процессов очень важен для формирования государственной политики развития. Поэтому в данном исследовании анализируется взаимосвязь между производительностью труда и объемом выпуска инновационной продукции, а также выявляются сходные процессы в отдельных регионах России и Казахстана.

Bblвoдbl: Согласно полученным результатам, были приняты следующие гипотезы: в Казахстане и России производительность труда напрямую влияет на инновационный выпуск продукции. Это влияние различно по регионам обеих стран. В Казахстане и России существуют регионы, схожие по характеристикам процессов влияния производительности труда на инновационный выпуск, и для них рекомендованы схожие меры совершенствования государственной политики.

Ключевье слова: производительность труда, инновационное производство, кластерный анализ, непараметрический анализ среды функционирования (DEA), Россия, Северо-Западный федеральный округ, Казахстан.

\section{References}

Bernanke B.S., Parkinson M.L. Procyclical labor productivity and competing theories of the business cycle: some evidence from... //Journal of political economy, 1991. - V. 99, — No 3, 439-459.

Farrel J. Michael, The measurement of Productive efficiency. //Journal of the Royal Statistical Society, Series A, General 125, 1957. - Part 2. - 252-267.

Garcia P., Knights P.F., Tilton J.E. Labor productivity and comparative advantage in mining: the copper industry in Chile. //Resources policy, 2001. - V. 27, No 2, - 97-105.

Голикова: вопрос о зарплате при переходе на 4-дневную рабочую неделю остается открытым [Электронный peсурс] // Сайт Информационного агентства «ТАСС» (https://tass.ru/ekonomika/6539080).

Горидько Н.П. Особенности экономического развития регионов Севера и Арктики: рынок труда и регрессионное моделирование потенциального валового регионального продукта [Текст] / Н.П. Горидько // Региональная экономика: теория и практика. - 2016. - № 5. - С. 121-136.

Сравниваем. Заработная плата в странах СНГ в 2018-м году [Электронный ресурс] // Сайт Информационносправочного портала «Banki 24.by» (https://banki24.by/news/3113-sravnivaem-zarabotnaya-plata-v)

Lovegrove N.C., Fidler S., Harris V.J. (1998). Why is labor productivity in the United Kingdom so low? McKinsey quarterly, 4, 44-57.

Kazmina I., Lukyanov P., Zhminko N., Savchenko I., Yusupova G., Zatsarinnaya E. (2020). Fourth industrial revolution-engineering innovations for labor productivity increasing. Talent development and excellence, V. 12, No 1.3, 477-487.

Медведев: будущее - за четырехдневной рабочей неделей [Электронный ресурс] // Сайт Информационного агентства «Вести.ru» (https://www.vesti.ru/doc. html? id=3156958).

Минакир П.А. Работать нельзя отдыхать [Текст] / П.А. Минакир // Пространственная экономика. — 2019. T. 15. - № 3. - C. 7-19. 
Миропольский Д.Ю. Состояние и перспективы развития трудовой миграции России с государствами-членами ЕАЭС как фактор устойчивого социально-экономического развития [Текст] / Д.Ю. Миропольский, Г.В. Якшибаева // Изв. СПб. гос. экон. ун-та. — 2018. — № 4 (112). — С. 29-37.

Мраморнова О.В. Возникновение и развитие прекариата в Российской Федерации и Республике Казахстан: сравнительный анализ [Текст] / О.В. Мраморнова, Н.А. Иванова, Ж.У. Абуова // Изв. Сарат. ун-та. Новая сер. Сер. Экономика. Управление. Право. — 2018. - № 18 (3). — С. 259-266.

Mukhopadhyay T., Lerch F.J., Mangal V. (1997). Assessing the impact of information technology on labor productivity a field study. Decision support systems, V.19, No 2, 109-122.

Официальные курсы иностранных валют в среднем за период [Электронный ресурс] // Сайт Национального банка Казахстана (https://www.nationalbank.kz/? docid=763\&switch=rus).

Петренко Е.С. Анализ состояния и перспективы развития горно-металлургической отрасли Казахстана [Текст] / Е.С. Петренко, Е.А. Вечкинзова, А.К. Уразбеков // Экономические отношения. — 2019. — Т. 9. — № 4. — C. 2661-2676.

Рослякова Н.A. Использование методики DEA для оценки перспектив инновационного развития Северо-Запада /Многофакторные вызовы и риски в условиях реализации стратегии научно-технологического и экономического развития макрорегиона «Северо-Запад» // Материалы Всерос. науч.-практ. конф., 23-24 октября 2018 г., ИПРЭ РАН. - СПб.: ГУАП, 2018. - С. 67-73.

Рослякова Н.А. Проблемы формирования и развития среднего класса в меняющемся мире [Текст] / Н.А. Рослякова, А.Б. Новиков // Изв. СПб. гос. экон. ун-та. — 2019. — № 4 (118). — С. 115-118.

Van Ark B. (1999). International comparisons of labor productivity and per capita income. Monthly labor review, V. 122, No.7, 33-41. 